\title{
Reconsidering the water system of Roman Barcino (Barcelona) from supply to discharge
}

\author{
Hector A. Orengo • Carme Miró i Alaix
}

Received: 30 May 2013/Accepted: 16 September 2013/Published online: 5 October 2013

(C) The Author(s) 2013. This article is published with open access at Springerlink.com

\begin{abstract}
This paper presents the results of the 'Roman Barcino Water Network' Project. This study employed a series of methodologies aiming at joining and interpreting all data available on water supply, distribution, management, use and discharge in the Roman colony of Barcino (modern Barcelona). Analyses of the results substantially modified previous knowledge of Barcino's water organization and provided one of the few examples in which the whole water system of a Roman city has been tackled. We concluded that the water supply employed a single aqueduct, which divided before entering the city and not two of them as it was previously assumed. Barcino's water distribution system was designed according to the different uses of water and was conditioned by the city's particular topography. The results also stress the colony's ample water availability, which despite its small size, allowed the maintenance of multiple public and private baths as befitted an accommodated population of merchants and administrators.
\end{abstract}

Keywords Aqueduct · Roman · Water network · GIS · Barcino (Barcelona)

\section{Introduction}

The importance of water acquisition, transport, distribution, management and drainage in the maintenance and development of human societies cannot be stressed enough. Water management systems are always associated to different cultural practices and each society perceives water in accordance to the physical environment, its cultural resources and its

\footnotetext{
H. A. Orengo $(\bowtie)$

Department of Archaeology, University of Nottingham, University Park, Nottingham NG7 2RD, UK e-mail: Hector.Orengo@nottingham.ac.uk

C. Miró i Alaix

Archaeology Service of the City of Barcelona, Institute of Culture of Barcelona, Carrer Comercial 5, $2^{\mathrm{a}}$ planta, 08003 Barcelona, Spain

e-mail: cmiro@bcn.cat
} 
social needs. In this sense, water supply was a key function of Roman public services, covering numerous public and private needs in Roman cities. Roman engineers were particularly efficient in designing and constructing water collection, transport, storage and distribution systems that supplied public and private baths, fountains, gardens and pools, dwellings and industries. Roman cities consumed significantly more water per person than modern ones, at least judging by the example of Imperial Rome (Forbes 1955; Hodge 2000, pp. 47-49). Therefore, it would not be a cliché to state that the core Roman culture was closely related to water usage. Not in vain, Pliny the Elder (Nat. 31.2) evokes the power of water to create cities. Important was also the choice of an adequate source of water. Different types of water were selected according to their intended use (Wilson 2001, p. 95), that being potable, industrial or recreational but also medicinal, sanitary or religious (Miró 2011a). Transporting water from far away sources could easily pay off the significant effort required when a constant and adequate supply was guaranteed and the water was pure enough. Roman authors, in fact, emphasized the importance of water quality (Vitr. De Arch. 8.4.1-2; Frontinus Aq. 1.11), which could save maintenance costs, preventing the settling of sinter on the channel walls or silt at the bottom. Roman engineers were, to a certain degree, more concerned about the quality and quantity of water supplied by a certain source rather than the distance the water had to be transported (Hodge 2000, p. 49; Malissard 2001, pp. 151-153), as demonstrated by numerous examples of enormous distances covered by aqueducts to obtain good quality water (Hodge 2002, p. 346).

Many authors find the Roman love for baths as the major reason of Roman aqueduct construction (Hodge 1989, p. 128; Owens 1991, p. 56; Kelly 2006, p. 317). Whatever the reason was, the water brought by the aqueducts covered many public functions and some private needs, forming an essential part of city planning and development. Barcino, as a Roman colony (Fig. 1), could not be an exception. The archaeological data available for Barcino, with many bathhouses in relation to its size and other water-consuming installations, renders evident the city's need for a constant and copious water supply. In the following sections all the previous research on Barcino's water network will be outlined and then deconstructed to suggest an alternative model, using a landscape/GIS approach. This study aims at an in-depth investigation of Barcino's water system, addressing issues of supply, distribution, use and discharge, but also, social aspects regarding public and private uses and access to water, in line with current agendas in Roman water research (Koloski-Ostrow et al. 2001).

\section{Barcino's aqueducts}

Since the 1960s Barcino's water supply is thought to have derived from different springs by means of two aqueduct lines. This was based on the discovery of two aqueduct channels in one of the gate towers of Barcino in 1958 (Duran i Sanpere 1962, p. 16; Serra Ràfols 1967, p. 132), which was the entrance of the water channels to the city for urban distribution. Excavations carried out in front of this tower (Blasco et al. 1992), unearthed a series of pillars corresponding to the two arcades bearing the channels found inside the tower. These findings were interpreted as being part of two aqueducts, the aqueducts of Montcada and Collserola (Vila and Casassas 1974, pp. 49, 52), which brought water to the city from different sources that joined at this point to enter the city through the same entrance.

Evidence of the so-called aqueduct of Montcada can be found in documents dating back to the tenth century, the earliest written documentation available for Barcelona. Additional 


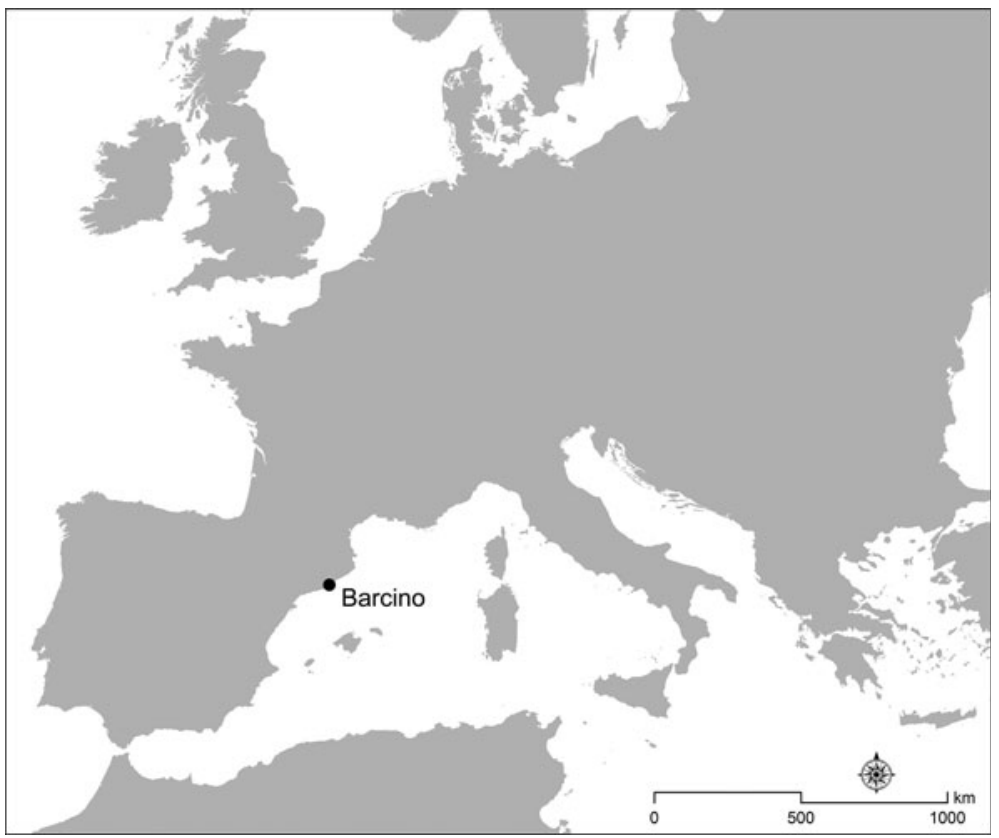

Fig. 1 Location of Barcino

evidence for the form and route of this aqueduct inside Barcelona's medieval quarter came with the discovery in 1987 of a preserved arcade of four contiguous arches, around $160 \mathrm{~m}$ away from the Roman gate. Furthermore, the recent discovery of a $93 \mathrm{~m}$ subterranean aqueduct stretch, $6.7 \mathrm{~km}$ north of the city (Giner 2006), corroborates the idea, already suggested by medieval documents, that this aqueduct supplied water from the springs located in the Montcada mountains, some $9 \mathrm{~km}$ north to the city. This conduit route has been generally acknowledged as coincident with that of Rec Comtal, an open channel constructed at the beginnings of the second half of the tenth century and used to supply hydraulic energy to numerous mills as well as water to irrigate several areas of Barcelona's plain. Early medieval documents and archaeological evidence seem to support this theory. The route followed by the Rec Comtal, unlike that of the aqueduct of Montcada, deviated before reaching the area of the ancient Roman city in order to provide water to the medieval industrial areas.

Regarding the second channel, the so called aqueduct of Collserola, analysis of seventeenth and eighteenth century documents and toponymic evidence led Mayer and Rodà (1977) following Vila and Casassas (1974) to suggest that the springs of Collserola Range were the origin of this second aqueduct. They also proposed a route for this aqueduct, which traversed Barcelona's plain in a straight line from Collserola to the entrance of the aqueducts in Barcino. According to these authors, this path was equivalent to that followed by the fourteenth century's pressurised piped conduit that supplied the fountains of Barcelona during the medieval and modern period (fourteenth-eighteenth centuries). Mayer and Rodà's theory has been accepted and reproduced without additions or alterations since the late 1970s. 
Water distribution inside the city

Up to now, there has been little research on water distribution and management inside the Roman city. Travesset (2005) has suggested the existence of a castellum aquae at the spot where the aqueduct channels enter the city. However this theory seems very unlikely due to archaeological and topographical reasons (Puig and Rodà 2007; Miró and Orengo 2010). The existence of numerous baths, both public and private inside such a small city, suggests that the city had a generous water supply. However, the study of these baths has been restricted to architectural and decorative aspects. A comprehensive study has been recently published on the Roman sewage system (Beltrán de Heredia and Carreras 2011) although a complete picture of the city's drainage is still dependent on new archaeological data.

\section{Roman Barcino Water Network Project}

In this section the results of a project dedicated to the study of sources, transport, distribution, use and disposal of water in the Roman colony of Barcino are presented. The project commenced in 2009 and it initially aimed at compiling all the sources and available evidence referring to the collection, distribution, management or drainage of water in Roman Barcelona (Miró and Orengo 2010). These sources can be divided into epigraphic, documentary and textual evidence, ancient maps, illustrations, old photographs, archaeological excavations and standing structures.

The next stage of the project included the analysis of the Roman aqueducts of Barcino: investigation of the natural springs and sources from which they could have been supplied, the technical characteristics of the conduits and their route until they enter the urban nucleus. The last stage covered the study of water distribution, its different uses, both public and private, the water-related structures and water drainage inside the city.

\section{Methodology and sources}

Most of the early research carried out on Roman hydraulics has been directed towards the architectural, monumental or artistic character of water related structures (De Haan in Koloski-Ostrow et al. 2001, p. 99). Since the 1980s, however, some studies have been published that analyse aqueducts as part of a complex territorial intervention process (Ventura 1996; Arenillas et al. 2009; Lagóstena and Zuleta 2009). More recently integrated studies analysing the water system of Roman cities as a whole are starting to be published (e.g. Ortloff and Crouch 2001; Crow et al. 2008; also the project 'Aquae Urbis Romae: the Waters of the City of Rome' conducted by K.W. Rinne), but they still remain rare (Fabre et al. 2005, p. 5; Crouch in Koloski-Ostrow et al. 2001, p. 98; Wilson in Koloski-Ostrow et al. 2001, p. 101).

The methodological approach of this study was designed to analyse the whole of Barcino's water system in an integrated way by employing techniques usually applied to landscape research and, therefore, it has a strong geographical and topographical basis. The use of Geographic Information Systems (GIS) was core. The first step was the development of a GIS-linked geodatabase in which all documents referring to the Roman water management system could be incorporated.

The insertion of old maps was essential since they would allow the reconstruction of the medieval city's layout and its environments. This was the only way to find the exact 
location of the medieval descriptions of the aqueduct's remaining ruins. The methodology followed is that described in Orengo and Fiz (2008): to introduce old maps into the GIS, they have to be georeferenced. The significant urban changes that took place in the city since the seventeenth century made it impossible to find appropriate ground control points (GCP) for georeferencing the oldest city maps. A regressive georeferencing methodology had to be applied in order to overcome this problem. A series of GCPs were identified on modern maps, which allowed georeferencing nineteenth century maps. From these, eighteenth century maps were in turn georeferenced and, finally, from these maps it was possible to obtain GCPs, which allowed georeferencing the oldest maps available, previous to the large-scale modifications of the city. The use of chronologically intermediate maps has been essential to relate modern maps to the oldest ones, ensuring thus their correct geographical referencing. Root-mean-square error (RMSE) values resulting from the georeferencing process were interpreted as an indication of the accuracy of the various maps. Once developed, the map's geodatabase allowed the extraction of features of interest such as the city's layout, architectural elements, building plots, streets and, most importantly, toponymic data, such as old street names and features including churches, convents, fountains, bridges or landscape landmarks.

1:2.000 aerial vertical photographs taken in 1947 were orthorectified and georeferenced. These are important sources due to their early date where much of Barcelona's surroundings were still dedicated to agriculture unlike their modern urbanised character. These photographs, together with old maps, permitted the reconstruction of the trace of Rec Comtal medieval water conduit, which was an important element for the further reconstruction of the aqueduct of Montcada.

Written documentation regarding missing hydraulic structures, standing remains and archaeological data were also incorporated into the GIS. When preserved, water circulation levels were also recorded, taking special care to obtain accurate height measurements.

Then, two digital terrain models (DTMs) were incorporated. The first DTM covered the whole territory of Barcino (see Palet et al. 2011, p. 117 for technical details). The second DTM covered the area of the ancient Roman city layout and its immediate surroundings and it was purposely built for this research. This high resolution DTM of $2 \mathrm{~m}$ per cell was developed from the digitalization of $1 \mathrm{~m}$ contours from the "Plano topográfico-geométrico de la ciudad de Barcelona, proyecto de reforma general" drawn by Miquel Garriga i Roca in 1861. Spot heights, obtained from excavated Roman soil levels, were also added to the model in order to correct the 1861 topography and improve its applicability to the topographical study of water movement in Roman Barcino.

From the aforementioned sources several analyses were developed by employing GIS. The Least-Cost Route analysis (LCR) was the first one. This GIS-based topographic analysis aims at tracing the most efficient route between two points according to the topography. LCR analysis has been mainly employed in the reconstruction of ancient pathways and roads (Van Leusen 2002; Fiz and Orengo 2008). This technique has also been applied to reconstruct the route of aqueducts (Roldán et al. 1999; Lagóstena and Zuleta 2009, pp. 165-166). Aqueducts are landscape structures, they adapt to the territory's topography to a certain extent (Lewis 2001, pp. 167-195) making LCR analysis an especially appropriate tool to analyse them. Thus, an LCR adapted to the specific needs of aqueduct route modelling was developed (for the specific technical details of the model see Orengo and Miró 2011). The route thus modelled avoided uphill slopes and those downhill slopes exceeding a gradient of $17 \mathrm{~m} / \mathrm{km}$. Beyond this value, Roman engineers would prefer techniques such as cascades or arcades which would enormously increase the aqueduct's 
cost. In this way, the trace modelled would follow a moderate downhill route, adapting thus to the standards of Roman engineering works.

The aforementioned model was employed for the simulation of both conduits' paths. For the simulation of the aqueduct of Montcada, the LCR's starting point was the adit of Montcada's spring, the origin of the Rec Comtal medieval open channel. This point was selected because of the unsurpassed quality and quantity of its waters. Moreover, a document dated to AD 987 mentions the existence of an ancient channel of water close to this source (document from AD 987, CSCugat, 344, doc. 981, in Travesset 2005, p. 43). The LCR's endpoint was the aqueduct entrances at the Northern gate of Barcino. Following Mayer and Rodà's hypothesis, Sant Genis dels Agudells was selected as the origin point for the simulation of the aqueduct of Collserola (1977, p. 269). As in the case of the aqueduct of Montcada, the endpoint of Collserola's Aqueduct LCR was the Northern gate of Barcino.

GIS was also employed to study, in a three-dimensional environment, water distribution inside the Roman city taking into account the topography and the little archaeological evidence available. The possibility of visualising the water-related structures with real heights in a 3D environment allowed the analysis and hypothetical reconstruction of the city's water network, taking into account the principle of constant hydraulic motion.

\section{Results}

The aqueduct of Montcada

The integration of written records and archaeological data demonstrates that the aqueduct of Montcada follows a clear path inside the medieval city of Barcelona (Fig. 2). Data on the aqueduct trace are much sparser outside the city and only four indications of its passing through Barcino's hinterland could be found (Figs. 2, 3).

The first evidence of its trace can be found in the aqueduct entrances in Barcino's Northern gate tower (Fig. 2a). Archaeological excavations in the Plaça Nova (Blasco et al. 1992), the square in front of the city gates, have unearthed a series of parallel aqueduct arcade pillars (Fig. 2b) corresponding to the aqueduct entrances in the city gate tower. These have been interpreted as the arcades of the two aqueducts. Multiple medieval sources attest the passing of a single arcade aqueduct through Capellans street (Carbonell 1547, fol. 4v, which calls this street 'lo Mal Cuynat'; Pujades 1609; Bosarte 1786). These arcades were probably preserved until the first half of the nineteenth century when Céan Bermúdez (1832) identifies fragments of an aqueduct in the street's southern entrance. Cardoner $^{1}$ and later on Fernández Casado (1972) and Sol (1977, pp. 381-382) have also attested the existence of aqueduct arcades and pillars inside a house built in this same spot. Further north, a complete section (4 arcades (Fig. 2c) and the water channel running on top of them (Fig. 2d)) of the aqueduct of Montacada was found preserved as part of a medieval building wall in Vuit de Març Square (Caballé et al. 2002). The next documentary evidence is to be found close to the convent of the Magdalenes (Iorba 1589, p. 19), in the nowadays disappeared arch Volta de l'Heure, between Montesió and Magdalenes street (Carbonell 1547, fol. 4v; Pujades 1609, p. 85). The next evidence is an excavated arcade pillar (Fig. 2e) at number 25 Magdalenes street (Griño 2005; Soberón 2005). According to documentary sources the aqueduct's route continues close to the medieval Palau Comtal

\footnotetext{
${ }^{1}$ Handwritten note in the archive of Francesc Cardoner in the Documentation Centre of the MUHBA.
} 


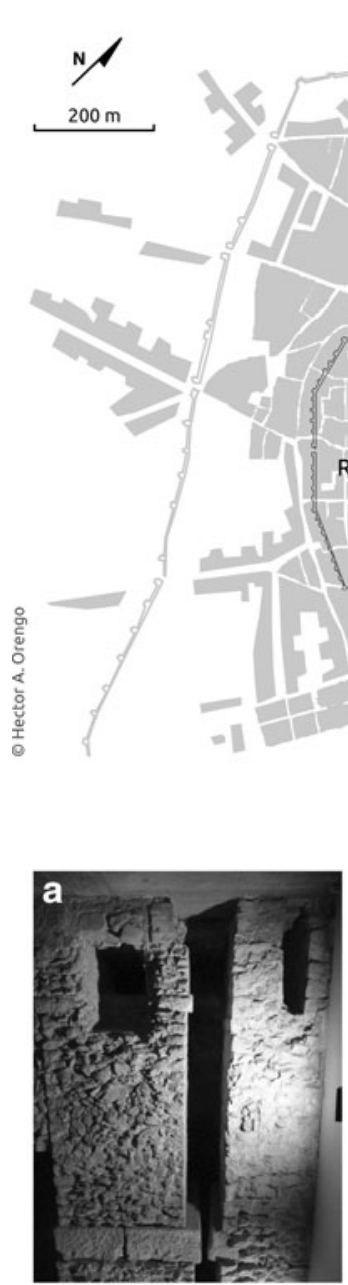

Aqueduct entrances into the city. Photograph N. Miró. Documentation Centre of the ICUB
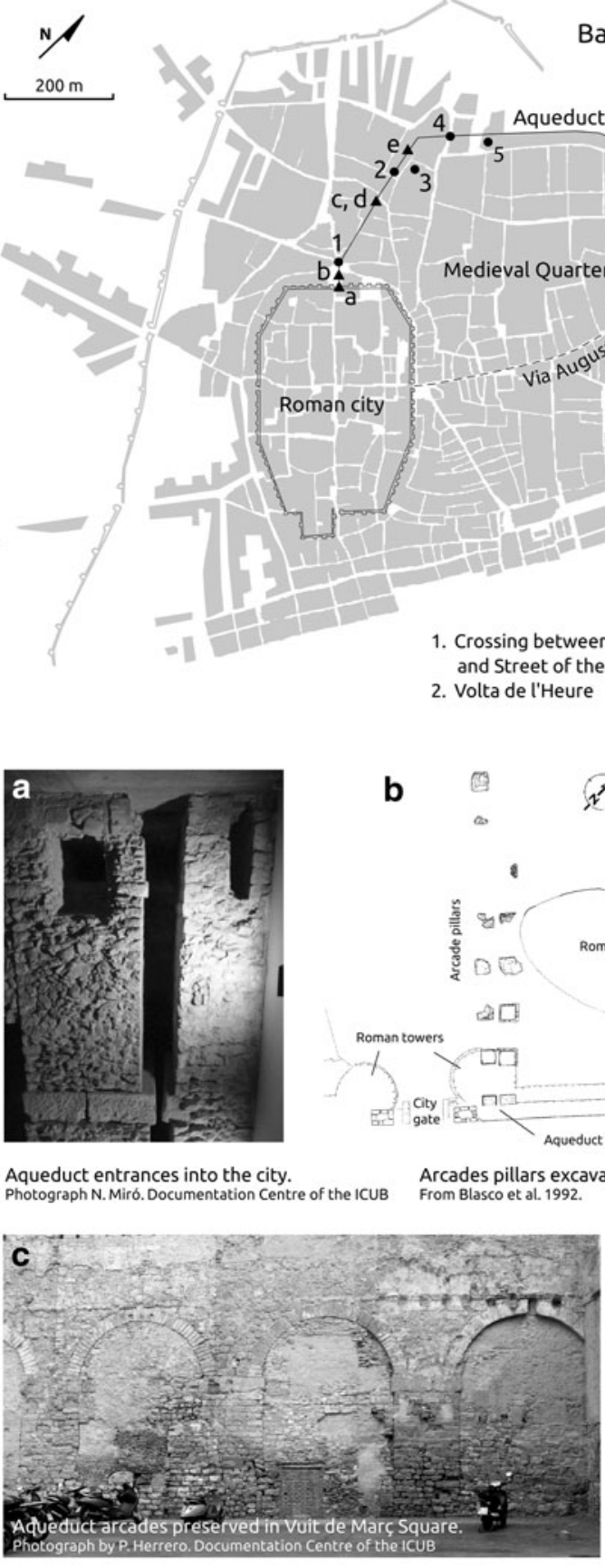

\section{Barcelona ca. 1280 \\ Barcelona ca. 1280}

$+\frac{6}{6}$

Medieval Quarter

b:

T.13 via $A$ avos

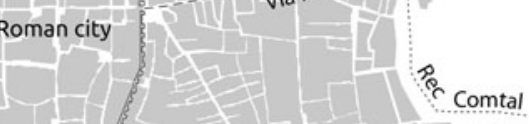

$1-13$ comtal

Lif

1. Crossing between Capellans and Street of the Arches.

2. Volta de l'Heure

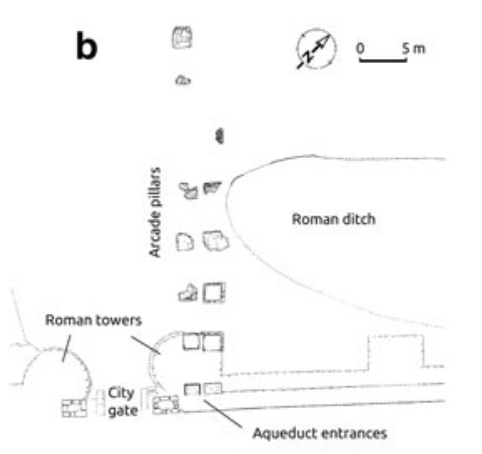

Arcades pillars excavated in Plaça Nova.
From Blasco et al. 1992.

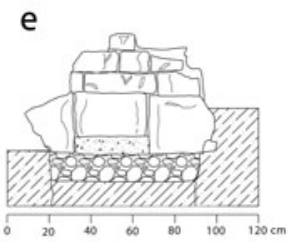

Arcade pillar found in 25 Magdalenes Street. From Soberón 2005.

3. Convent of the Magdalenes

4. Arches of Jonqueres Street/ County palace

5. Convent of Sant Francesc de Paula

6. Convent of Sant Pere

7. Celada hill

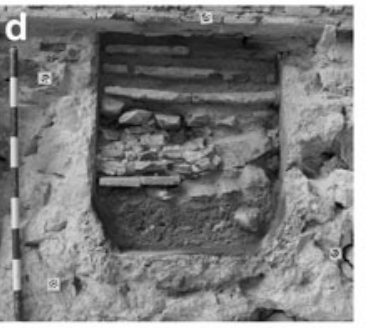

Aqueduct channel in Vuit de Març Square. Photograph by V. Triay. Documentation Centre of the ICUB

Fig. 2 Evidence for the route of the aqueduct inside the medieval city 

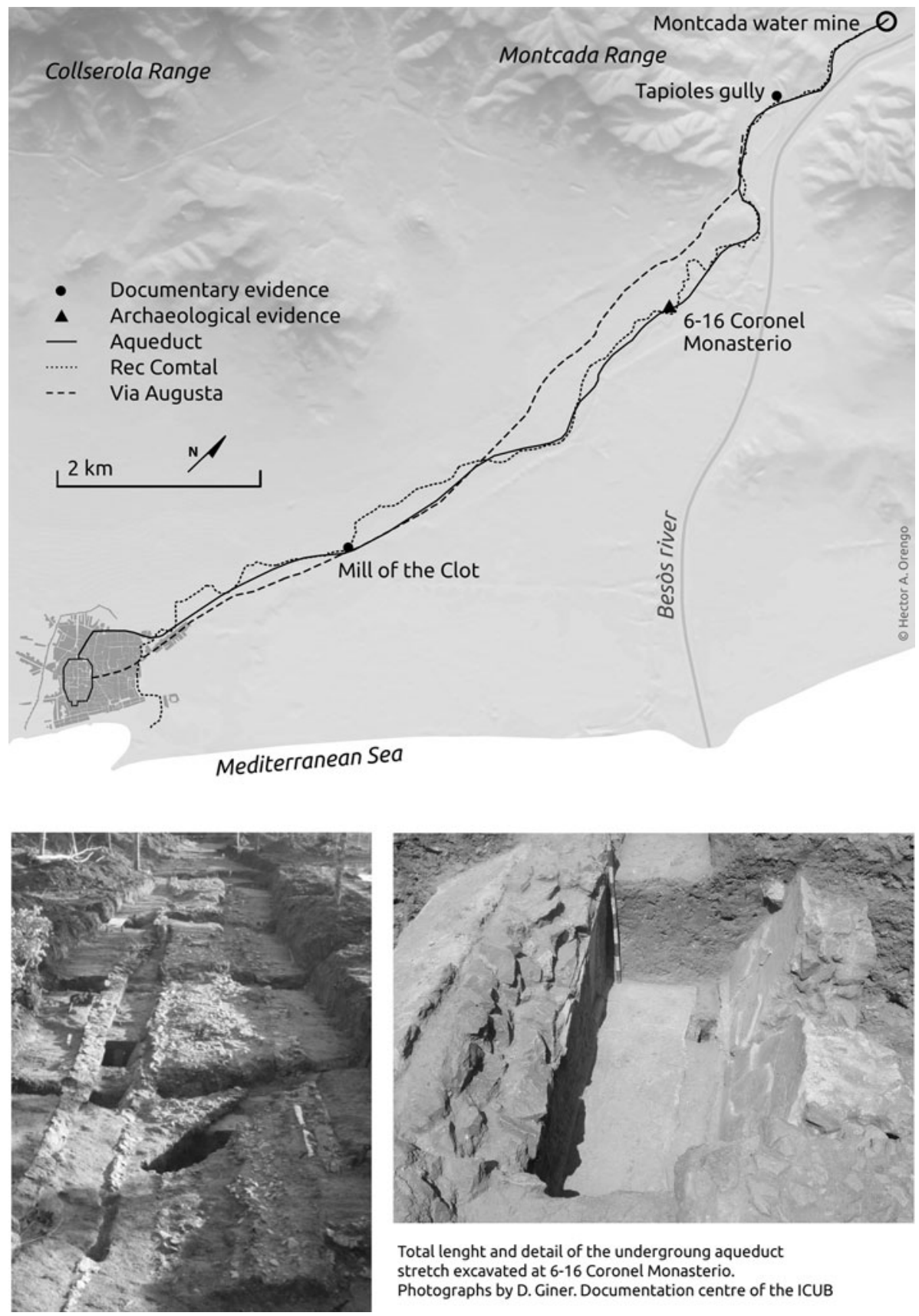

Total lenght and detail of the undergroung aqueduct

stretch excavated at 6-16 Coronel Monasterio.

Photographs by D. Giner. Documentation centre of the ICUB

Fig. 3 Evidence for the route of the aqueduct in the city's hinterland

Menor (document from AD 1116, ACA, Ramón Berenguer III, no. 191, in Mayer and Rodà 1977, p. 272) in the currently disappeared Carrer dels Arcs de Jonqueres (Jonqueres's Arches Street). This spot would correspond to the crossing between Via Laietana, 
Magadalenes street, and Jonqueres street. To reach this point the aqueduct traversed the socalled Jonqueres stream, known as Merdanciano or Merdançar in the early medieval period. An early medieval document (dated to AD 1029, ACA, Berenguer Ramón I, no. 73, in Carreras Candi 1905, p. 185) attests the aqueduct passing. It is possible to suggest the aqueduct had a double arcade to overcome the stream, which is still evident in this spot in the nineteenth century topography. According to Carreras Candi, several documents seem to suggest the existence of a double arcade stretch, although these are imprecise as to its location (Carreras Candi 1905, p. 185).

Further documentary evidence suggests that the trace continued through Sant Pere Més Alt street, close to the medieval convent of Sant Francesc de Paula (Carbonell 1547, fol. 4v; Pujades 1609, p. 85) (located where the Palace of Catalan Music stands now). The last documentary evidence inside the medieval city's layout indicates that the aqueduct passed close to the convent of Sant Pere (document from AD 1044, CSCugat II 575, p. 240, in Balari Jovany 1964, p. 240; Pujades 1609, pp. 84-88), the area where the Rec Comtal enters the medieval city through the Portal Nou gate.

Outside the medieval city, both Carbonell (1547) and Pujades (1609) indicate the presence of aqueduct remains between Sant Adrià and Horta roads. Another document (from AD 993, Lantiq. I 23, fol. 11 V, in Mayer and Rodà 1977, p. 266) indicates the presence of ancient arches close to the Celada hill, that is, between the Sant Adrià and Horta roads. This document links the arches with the trace of the Roman via Augusta as documented by Palet (1997). Bosarte (1786, p. 20) also comments on the presence of remains of the aqueduct in this area at the end of the eighteenth century. Pujades (1609, p. 85) further identifies the presence of another aqueduct stretch close to the Clot mill, which was served by the Rec Comtal. Further north-east, an archaeological excavation in 6-16 Coronel Monasterio street (Giner 2006) has unearthed a $93 \mathrm{~m}$ long stretch of the underground tract of this aqueduct (Fig. 3). This conduit, equal in size to those encountered in Barcino's aqueducts entrances and in Vuit de Març Square, runs parallel to both Rec Comtal and via Augusta. The closest documentary evidence to Montacada springs of the aqueduct trace comes from a document from the Cartulari de Sant Cugat del Vallès dated to AD 987 (CSCugat, 344, doc. 981, in Travesset 2005, p. 43). The text refers to a land plot near "ipsa Aquaria antiqua vel in via". This land plot is located at the Sant Joan hill at the point where via Augusta crosses the gully of Tapioles (Fig. 3).

The location of archaeological evidence, standing structures and, less accurate but more numerous, documentary sources provide a patchy image of the path followed by the aqueduct of Montcada. The route resulting from LCR analysis from the spring of Montcada to the aqueduct's entrance into the city completes this picture with a continuous itinerary, which joins the previously exposed archaeological and documentary evidence of the Roman aqueduct (Fig. 3). The modelled path also shows a striking similarity to that of the Rec Comtal as reconstructed by cartographic and photographic interpretation.

The conjunction of all this data is enough to offer some technical data on the aqueduct of Montcada. The aqueduct's total length is $11.3 \mathrm{~km}$ with a height difference between the water source and the aqueduct entrance in Barcino of $18.12 \mathrm{~m}$, which equals an average slope of $1.6 \mathrm{~m} / \mathrm{km}$.

Both archaeological evidence and the few remaining standing elements of the aqueduct of Montcada show that the aqueduct's specus was $60 \mathrm{~cm}$ wide in both the underground conduit and the arcade sustained channel. The walls of the underground vaulted conduit were $35 \mathrm{~cm}$ thick and made of opus caementicium. The aqueduct had a total width of 
$1.3 \mathrm{~m}$. The inner walls were plastered up with hydraulic mortar or opus signinum, which is usual in this type of structures. The walls had a height of $1 \mathrm{~m}$ until the start of the vault, which makes for a channel $1.3 \mathrm{~m}$ high. The aqueduct arcades kept an average distance between them of $5.5 \mathrm{~m}$, varying between 5.15 and $5.9 \mathrm{~m}$. The conduit on top of the arcades was also covered to keep the temperature of the water low and avoid possible contamination but fitted slabs of sandstone were preferred instead of a vault, as was usual for overground channels.

\section{The aqueduct of Collserola}

The so-called aqueduct of Collserola has much less documentary evidence for its route and the only archaeological data are the aqueduct entrances (Fig. 2a) and the arcade pillar bases found in the excavation at the Plaça Nova (Fig. 2b). It has been traditionally considered on the basis of toponymic evidence that this aqueduct followed the Street of the Arches. This street was previously known as Paso de la Moranta. A document from AD 988 attests the presence of arcades in this street: "archos anticos ubi dicunt Paso de Moranta" (ACA Montalegre 626, in Mayer and Rodà 1977, p. 271). Pujades writes in 1609 that his grandmother found the pipes of the old aqueduct during masonry work in some houses of the Street of the Arches.

From the eighteenth century onwards there are many sources indicating that this aqueduct taped the springs at Collserola, an area that can be identified with the modern Tibidabo (Ponz 1788, pp. 62-63; Ceán Bermúdez 1832, p. 15; Laborde 1974, p. 71).

Toponymic evidence leads Mayer and Rodà (1977) to propose Sant Genís dels Agudells as the original source tapped by this aqueduct. In fact, a document dated to AD 1445 attests the acquisition of water from 'Sent Genis Degudells' by the city council (Schwartz and Carreras Candi 1892, pp. 385, 481).

Mayer and Rodà (1977) also propose a straight route for this aqueduct from Collserola to the Roman city's northern gate. As the authors acknowledged this route coincides with the city's medieval water supply system as described by Socies in the seventeenth century (1650).

The results of the LCR analysis conducted between Sant Genis dels Agudells and the aqueduct entrances in Barcino's northern gate also highlight the strong resemblance with the route followed by the medieval pressurised water conduit. Once outside the Collserola range the aqueduct would have traversed the plain in a straight line following Camí de Jesús, known as Passeig de Gràcia avenue since the Modern period. The hypothetical restitution of the aqueduct trace from Sant Genís dels Agudells resulted in a $6.4 \mathrm{~km}$ long route with an average slope of $38.45 \mathrm{~m} / \mathrm{km}$. This is an extremely high value which could be reduced if only the stretch traversing the plain is considered. In this case the trace is reduced to $2.98 \mathrm{~km}$ and the slope would equal $17.87 \mathrm{~m} / \mathrm{km}$.

\section{Water distribution inside the city}

The first evidence is, naturally, the two aqueduct channels' entrance through the city's northern gate tower (Fig. 2a). The height of the specii of the aqueducts is 16.88 m.a.s.l. for the right channel (according to water flow) and 16.70 for the left channel. Another important evidence for water conduction inside the city is the so called 'cloaca maxima' (Fig. 4c). It is located along the axis of Palma de Sant Just Street and it has been 
traditionally interpreted as a Roman sewer. ${ }^{2}$ Three perpendicular channels have been documented connected to it. A report dating back to the end of the nineteenth century ${ }^{3}$ mentions the excavation of the chaplains' crypt in the church of Sant Just i Pastor in 1852. The crypt, constructed in 1345, intersected a previous conduit. The conduit was walled up and the word "acaducto" was incised in both sides of the crypt, in the points were the crypt cut the older conduit. The report describes the excavation of this conduit in such a way that it clearly coincides with that of the so called 'cloaca maxima'. Also, there is a map of the excavated part of the conduit that shows that the conduit continues through Palma de Sant Just Street, following the same route as the previously described 'cloaca maxima' (Fig. 4b). Despite the formal similarities in size and construction between this and the other stretches of the aqueduct documented this conduit's specus and walls were not covered with hydraulic mortar or opus signinum as documented for other stretches. Another similar channel to that discovered in Palma de Sant Just Street and the church of Sant Just i Pastor was found at Pietat Street during maintenance work in the 1950s. Although, the only available information for this channel is some photographs, these are enough to show the similarity to the channel at Sant Just.

Some water pipes for the pressurized distribution of water have also been discovered in the city. Except for a ceramic pipe discovered in the suburbs of the city (Miró 1998), (Fig. 4e) all the others are inside the walled city and are made of lead (Fig. 4d). The latter show a characteristic pear-shaped section with a variable external diameter of circa $10 \mathrm{~cm}$.

Modern excavations have also been able to document other water related structures in the urban area of Barcino. The most evident are various baths, or balnea, both private and public. These were mostly located in the southern part of the city, at a lower height (Fig. 4).

Modern excavations have also unearthed evidence of hydraulic structures in the higher northern part of the city. There are several lacus or ponds associated to cult buildings, the so-called Domus de Sant Iu and the temple of Augustus. The Domus de Sant Iu has been recently reinterpreted as a collegium, probably a collegium augustalis or augusteum (Cortés 2009; Orengo and Cortés 2014). The peristylium was decorated with a nymphaeum from which three pools have been preserved.

Recent archaeological work close to the temple of Augustus (Puente 2005), located in the higher area of the city, led to the documentation of a lacus surrounding this structure (Miró and Orengo 2010, p. 125; Orengo and Cortés 2014).

The industrial area of the city, also in its northern part (Fig. 4), under the Plaça del Rei, presents a fullonica and a tinctoria from the 2nd century $\mathrm{AD}$, a cetaria from the 3rd century AD and a wine installation from the second half of the 3rd to the 4th century AD. All these industries would have required an enormous amount of water for their function. The complex drainage system discovered in these installations (Beltrán de Heredia and Carreras 2011) (Fig. 4) points also to their intensive use of water.

In addition, a number of sewers have been found in the central axis of some of the streets of Barcino (Fig. 4). They are square in section with sizes varying from $60 \mathrm{~cm}$ wide per $90 \mathrm{~cm}$ high in the cardo maximus to $30 \times 45 \mathrm{~cm}$ in the cardines minoris. They usually

\footnotetext{
2 The conduit discovered in 1852 (see note 3), was reexplored in 1901 (Duran i Sanpere 1972, p. 30), and the continuing stretch in Palma de Sant Just street has been excavated in two occasions in 1928 by Duran i Sanpere (1972, pp. 28-30) and 1973 by Francesc Cardoner.

3 The report of the 1852 excavation was published by Mestres (1893). Previous to this excavation, Villanueva (1851, p. 157) documents the finding of subterranean cavities in the church in 1723 .
} 

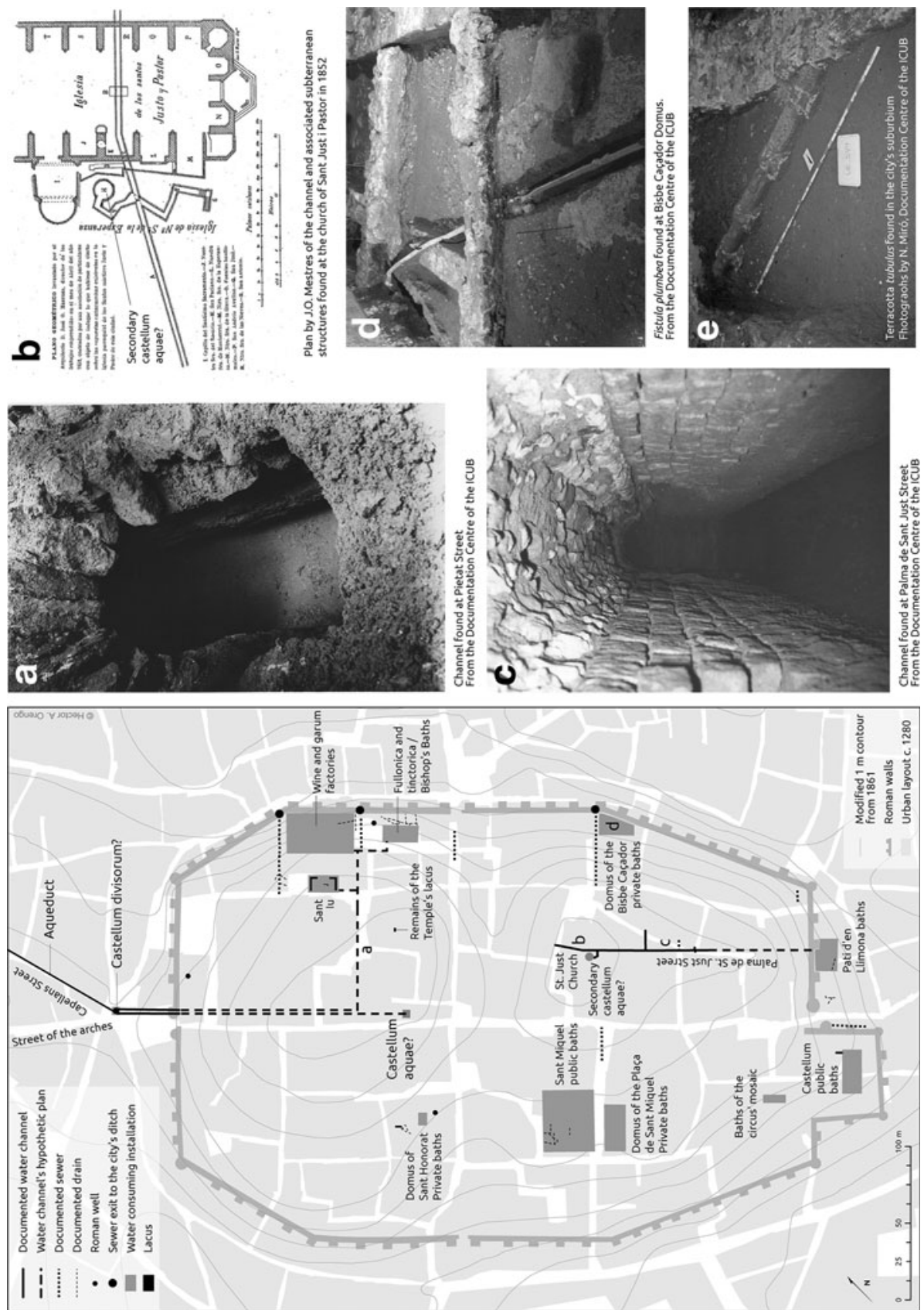

Fig. 4 Water-related structures inside the Roman city

employ one or two tegulae (according to the sewer size) as flooring and the walls are made of irregular stones joined with mortar and are covered with stone slabs of variable size (Beltrán de Heredia and Carreras 2011). 
Disconnected from the water supplied by the aqueduct, are several Roman wells excavated in different spots of the city. In addition, the excavations in the Passeig Picasso have unearthed four wells lined up, which could have played a major role in the water supply of this area of Barcino's suburbium.

\section{Discussion}

The water supply or on how Barcino lost an aqueduct

Considering all the data provided by the different sources referring to the aqueducts of Barcino and the GIS-based topographic analysis, the Roman origin of the Montcada aqueduct becomes evident.

Several documents from the tenth and eleventh century confirm the path of the aqueduct from its start in the springs of Montcada to its passage through the medieval city. These documents are of outstanding importance since they refer to structures which were already ancient in the tenth and eleventh centuries and therefore could have not referred to the Rec Comtal open channel built at the beginning of the second half of the tenth century (Aguelo et al. 2011, p. 333). Also these documents prove that, in the early middle ages, it was common knowledge that these remains belonged to an already ancient aqueduct as proven by many examples such as "Aquaria antiqua" (document from AD 987, CSCugat, 344, doc. 981, in Travesset 2005, p. 43) or "in prenotatis archis priscis unde olim aqua consueuit decurrere" (document from AD 1017, Ant. Eccl. Cath. Vol. I, fol. 122, doc. 599, in Carreras Candi 1905, p. 185). This knowledge survived until the late middle ages as demonstrated by the identification of the aqueduct's channel when found during the excavation of the crypt in the church of Sant Just i Pastor.

Standing structures and archaeological evidence further attest its route and provide data to assess its construction process and its final layout. Therefore, it seems that most of the aqueduct tract was underground and it only relied on the use of arcades when the topography made it necessary or for monumental purposes as the aqueduct was approaching the city. The use of arcades has made the Roman aqueduct more visible in the medieval period and, in fact, most documents refer to the arches rather than the aqueduct itself. This might be part of the reason for which more medieval documentary evidence exists for the last part of its route and fewer for the hinterland where it ran underground. As previously mentioned, the closest documentary evidence to the origin of the aqueduct is located in Sant Joan hill where the variable topography probably made necessary the use of arcades or a contour-following rock-cut conduit, enhancing in this way the visibility of the aqueduct.

GIS-based topographic analysis provided a hypothetical route and a profile well adapted to both archaeological and documentary evidence. In particular, results of LCR analysis provided an average slope of $1.6 \mathrm{~m} / \mathrm{km}$. This is a rather conservative gradient for a Roman aqueduct according to the standards recorded in the archaeological bibliography (Lewis 2001, pp. 174-177; Hodge 2002, pp. 216-219, 347-348). There is indeed some divergence amongst Roman authors: Vitruvius (De Arch. 8.6.1) recommended a slope of $5 \mathrm{~m} / \mathrm{km}$, whereas Pliny (Nat. 31.31), closer to the archaeological evidence, stated that the ideal slope had to be $0.2 \mathrm{~m} / \mathrm{km}$. In any case, the slope of the aqueduct of Montcada falls well within the standards of Roman engineering. 
The relationship between the Rec Comtal and the aqueduct of Montcada can also be confirmed. This might be due to the use of the Roman aqueduct as a topographical guide for the construction of the Rec Comtal. This is a rather common practice in medieval and post-medieval water engineering, as attested in the neighbouring Tarraco (modern Tarragona) (López 2008, p. 368; see also Leveau 2004). In this case, however, as the Rec Comtal channel was mainly meant for the provision of hydraulic energy to the mills of the Count of Barcelona, located along its route (Ortí 2012), the Rec Comtal follows a more sinuous trace in order to increase water energy at the spots where the mills are located (Orengo and Miró 2011). There is also a clear spatial relationship between the aqueduct trace and that of the Via Augusta as its trajectory also goes from the Roman city to the Finestrelles pass, that is, close to the springs of Montcada (Palet 1997). The association between routes and Roman aqueducts is also common. Their adaptation to topography makes them easy to follow. The aqueducts' association with roads has also a practical benefit since they needed an easy access for maintenance and repairing works (Frontinus Aq. 17).

The evidence gathered for the aqueduct of Collserola shows a very different picture. There is no archaeological evidence or standing structure for this conduit. The documentary sources that make reference to its presence are mostly from the seventeenth century onwards and they probably refer to the medieval pressurized water system, since they usually refer to water pipes (Pujades 1609). Carreras Candi (1916, p. 392) documents the beginning of the works of the medieval water supply in 1347, which renders the system old enough to have been regarded as ancient in the seventeenth century. Another characteristic of post-medieval sources is that they only point to the existence of remains of this aqueduct in the Street of the Arches and on Collserola mountains. The documents previous to the seventeenth century only refer to the Street of the Arches. The street's name "carrer dels arcs vells" (street of the old Arches) is documented from at least the fourteenth century (Borau 2003, p. 178). Also a tenth century document indicates the presence of ancient arches in this street (Mayer and Rodà 1977, p. 271). Both data could have referred to the arches located at the end of the street when it enters in the Plaça Nova. These arches correspond to the by then still standing arcades of the pillars of the aqueduct excavated in the Plaça Nova (Fig. 2b). These would have been mostly visible when walking through this street towards the city centre. In fact, Alexandre de Laborde in 1801-1803 describes the existence of aqueduct arcades at the beginning of the Capellans Street. The first city maps already show these two streets joining to form a V. It is, therefore, possible that the various documents that mention the existence of aqueduct arcades at the street of the Arches and Capellans Street are referring to the same structures. None of these documents, in fact, mentions both streets having aqueduct arcades, it is either one or the other, which further proves they were referring to the same structures. As a result, the existence of the aqueduct of Collserola, on the basis of documentary evidence, becomes unfounded.

Also, the results of the LCR analysis indicate that the aqueduct of Collserola does not meet the Roman engineering standards: its gradient, even in the flatter part of its route, which equals $17.87 \mathrm{~m} / \mathrm{km}$, is higher than any known Roman unpressurised aqueduct.

It is also interesting to compare the water discharge of the different water sources. The spring of Montcada had, according to a technical enquiry conducted in 1895, a minimum discharge of $38,804 \mathrm{~m}^{3}$ per day (Martín 2007, p. 313) while Collserola's springs discharged around $300 \mathrm{~m}^{3}$ per day (Call i Franqueza 1878, p. 124). This is clearly an insufficient amount to justify the construction of a water conduit, particularly if the enormous quantity of water supplied by the Montcada sources is taken into account. 
Furthermore, the quality of water that these channels transported needs to be considered. The preserved stretches of the channel from the aqueduct of Montcada show no or very little $^{4}$ evidence of incrustation of calcium carbonate (sinter) within them. On the contrary, medieval documents that refer to the transport of water from the springs of Collserola range insist in the need for continuous cleansing of sinter deposits in the water conduit (Schwartz and Carreras Candi 1892, p. 385; Voltes Bou 1967, pp. 28, 38). In this respect, it is worth noting that the two channels entering Barcino had no traces of sinter.

All this evidence leads us to suggest that the Collserola conduit was of medieval origin. By the tenth century the Roman aqueduct had fallen into disuse. The Rec Comtal's waters were destined to industrial and agricultural functions and therefore many wells were excavated throughout the city to replace the water brought in by the Roman aqueduct. Some factors such as population growth or processes of desiccation and salinization of the wells probably forced the medieval authorities to construct this new conduit in order to supply the medieval city towards the mid fourteenth century.

Barcino had only one aqueduct, corresponding to the aqueduct of Montcada, which, considering the colony's size and the discharge of the springs of Montacada, was more than enough to cover its needs. The existence of two aqueduct entrances in the city must be related to a split of the aqueduct of Montcada before entering the city. The hypothetical castellum divisorium would have been located in the Plaça Nova. This is the exact point where the extension of the lines formed by the pillars at the Plaça Nova and those at Vuit de Març Square meet. The water transported by these two channels was destined to cover different functions within the city. The division of aqueducts to cover different functions is well attested with many known examples such as Kremna (Owens 1991) or the aqueduct of Eygalières in Arles, which deviated part of its flow to join the aqueduct of Caparon in supplying the Barbegal mills (Guendon and Leveau 2005). Closer to Barcino, the aqueduct of Gaià in Tarraco was also divided before entering the city to supply the provincial forum and the circus (López 2008, p. 367).

The earliest date available for this aqueduct is provided by the excavation of the underground conduit in Coronel Monasterio Street. The filling of the ditch excavated to accommodate the conduit provided several fragments of terra sigillata, of which a south Gallic Dragendorff 27b (between AD 40 and AD 80) and a Hispanic Dragendorff 29 (AD 40-50) provide an approximate date of middle first century for the aqueduct's construction. A ceramic fragment interpreted as an imitation of late African Red Slip ware, found in the filling of the aqueduct's channel, could date the collapse of the structure at the end of the sixth - beginning of the seventh century. This is also consistent with the construction of the late antique Bishop's Baths at the beginning of the sixth century in the place previously occupied by the tinctoria and the fullonica. This fact shows that the left channel was still supplying water to this area in the sixth century, after the destruction of the previous industrial installations. Water distribution to the southern sector of the city seems to have continued until the same moment. Hernández-Gasch dates the filling of the channel providing water to the Castellum baths between the late sixth century and the beginning of the seventh (2006, p. 89, no. 43).

\footnotetext{
${ }^{4}$ No sinter has been found in the channel at Vuit de Març Square or the channel entrances in the gate tower. However in the excavation at Coronel Monasterio a layer of calcium carbonate of $2 \mathrm{~cm}$ has been found (Giner 2006, p. 43), which, compared to sinter deposits in other Roman aqueducts such as those of Nîmes or Cologne, is a fairly scarce amount.
} 
Water distribution, use and discharge in the city: towards the characterization of an urban water network

Based on the previously gathered data and the use of topographic analysis, it is possible to provide insights into the colony's water system and, although hypothetically, to partially reconstruct the water network.

Water enters into the city by two channels; the right channel's specus is at a height of $16.88 \mathrm{~m}$. while the left channel's specus is at $16.7 \mathrm{~m}$, that is, $18 \mathrm{~cm}$ lower than the right one. From the aqueduct's specus in Vuit de Març Square, at a height of $17.15 \mathrm{~m}$, a slope of $1.66 \mathrm{~m} / \mathrm{km}$ can be derived for the right channel and $2.7 \mathrm{~m} / \mathrm{km}$ for the left one. The slope shown for the right channel is very similar to Montcada's aqueduct average slope of $1.6 \mathrm{~m} / \mathrm{km}$ and therefore its slope would remain the same regardless of the position of the castellum divisorium that marks the beginning of the double channel. On the contrary, the left channel slope is dependent on the position of the castellum divisorium. If we accept the previously proposed location of the castellum divisorium at the Plaça Nova, then the left channel slope increases to $6.5 \mathrm{~m} / \mathrm{km}$. These substantial differences in the aqueduct can help us determine their trajectory and the most probable areas of discharge. The right channel, with its height and slope, could have only discharged at the uppermost part of the city, in the colony's forum. At this point the height of the aqueduct would have been around $16.68 \mathrm{~m}$. Archaeological interventions document the circulation level in the upper area of forum at a height of between 14.75 and $14.81 \mathrm{~m}$ (Marín 2007). According to this data, the channel would discharge at a height of $1.9 \pm 0.03 \mathrm{~m}$ above the forum's circulation level, which was the highest area in the Roman city. This is an adequate height for the discharge of the aqueduct's water, as we should imagine a monumental castellum aquae with a cistern and a fountain and, perhaps, a nimphaeum, as it would be expected in such a privileged location. The castellum aquae must have provided water to the temple of Augustus with its surrounding pool, and in fact this location was the only spot from which water could have been diverted to the temple, given its topographically prominent location (Orengo and Cortés 2014).

The castellum's prominent location would have been ideally suited to distribute water through lead pressurised conduits, or fistulae plumbea to the western sector of the city where the commercial area and private residences were located. The only partially excavated domus in this sector, Sant Honorat domus, presents evidence of the presence of at least two ponds with a supplying and drainage system and a private bath complex (Florensa and Gamarra 2006). Although public fountains are common, piped water in Roman cities was not freely available to all citizens and a tax had to be paid to have access to the pressurised water system. The presence of wells is frequently attested in the affluent houses of Roman Barcino. Moreover, there was probably no shortage of domestic cisterns although, at the moment, only two have been documented: one in the domus of the Bisbe Caçador, probably associated to industrial functions, and the second in the domus at Plaça de Sant Miquel. These constituted a tax-free complement to the access to public water supply. However, given the peculiar topographical setting of Barcino, with a shorter elevation only $125 \mathrm{~m}$ south-west of the elevation where the temple is located, it would have been more difficult to provide an adequate water supply to the private and public baths located in the southern sector of the city. This function is probably served by the channel found in 1852 at the excavation of the chaplains' crypt in the church of Sant Just i Pastor, which is undoubtedly the same channel documented in Palma de Sant Just Street. It runs along the upper axis of the city (Fig. 4) through one of its minor decumanii, providing thus a perfect location for the distribution of water to the baths located in the lower southern 
part of the city. The finding of three perpendicular lateral channels also needs to be addressed. The first one probably connected this conduit to the Bisbe Caçador domus ${ }^{5}$. After its first phase, of which little is known, this domus' second phase presents a small domestic industry of oil or wine and a cistern ${ }^{6}$ with an outlet made of tegulae probably related to this activity. The domus' third phase, dated to the 4th century $\mathrm{AD}$, presents a rich bath complex (Miró 2011b, pp. 74-78). All this evidence attests to the domus' ample water consumption.

The two other channels tapping Palma de Sant Just conduit were left unexplored, the right one was directed towards lower sectors where baths such as those of the Plaça de Sant Miquel, ${ }^{7}$ the Circus' Mosaic and the Castellum baths were located. ${ }^{8}$ The channel would continue in a straight line until it reached the Pati d'en Llimona baths ${ }^{9}$ outside the city walls. It is interesting to note that this conduit's specus and walls were not plastered up with opus signinum. The lack of hydraulic mortar characterises Roman water conduits that are not meant to provide drinking water. Other examples can be found at the neighbouring Baetulo (Padrós 1999) or in Pamplona, where the channel was used for the supply of a bath installation (Unzu et al. 2006).

In this context, is interesting to note the inscription found in Barcelona in which Lucius Minicius Natalis father and son declare they have ordered the construction of a bath-house and the water conduit to supply them: "balineum c[um port]icibus solo suo et/du[ctus aquae] fecerunt" (CIL 02, $06145=$ CIL 02, 04509). These have been related to those of Sant Miquel (Rodà 1974, pp. 219-220, 330) given the public character and richness of this structure but also the proximity of the Sant Miquel baths to the spot in which the inscription was found, and the depiction, in one of the bath's pavements, of a chariot race. ${ }^{10}$ It is obvious the "ductus aquae" mentioned in the inscription cannot refer to the Montacada aqueduct due to the earlier date of the construction of the aqueduct. However, the Minicii Natales's construction of a ductus aquae to supply these baths may have referred to the conduit in Sant Just or one of the channels taping it.

Understanding the connection between the castellum aquae in the forum area and the channel found in the church of Sant Just i Pastor and Palma de Sant Just Street remains a problem. Given the topographic depression between these two areas, they could have been connected with an arcade aqueduct or an inverted siphon system, although no evidence exists to prove it. A secondary castellum aquae or distribution tower could be placed in the area around the church of Sant Just i Pastor, the highest spot in the city's southern elevation. Both the 1852 excavation at Sant Just i Pastor church and a latter exploration in 1901 (Duran i Sanpere 1962, p. 30) record a small underground circular room close to Sant

\footnotetext{
5 Duran i Sanpere (1972, pp. 28-29) documents this conduit, although later explorations have not yield any information about it. Its position and direction lead us to think it might have supplied the baths of the Bisbe Caçador Domus.

6 The cistern was not completely excavated (Cortés 2011) and therefore its size cannot be calculated.

7 Two balnea complexes has been found in this sector one private belonging to the Domus of the Plaça de Sant Miquel and another public knows as Sant Miquel Baths.

8 The size and rich feature of the circus' mosaic, part of a caldarium, points to its probably public nature. Although more evidence is still needed, these baths could have been formed part together with the Castellum baths, of which only a frigidarium or natatio is preserved, of a single bath complex.

9 Recently reinterpreted as a private bath complex (Miró 2011b).

${ }^{10}$ Lucius Minicius Natalis won the chariot race in the 227th Olympic games. He added to his family name, possibly to distinguish himself from his father, that of Quadronius Verus. The depiction of a chariot race in one of Sant Miquel baths' pavements further points to the identification of this building as the one paid for by the Minicii.
} 
Just i Pastor Church connected to the channel. This room had a low bench with holes attached to its walls. Although this description could be interpreted as that of a castellum aquae, the vagueness of the description and the irregularity of the plan made by Mestres (1893) cautions against this assumption until the room is fully examined.

Nonetheless, this secondary castellum could have facilitated the distribution of pressurised water to domestic contexts in this sector of the city that could have been difficultly reached by pressurised pipes tapping the forum's castellum. In fact, one of the few fistulae found in the city, and the only which we can locate with precision, was the one found in the Bisbe Caçador domus (Fig. 4d), a spot which could have been difficultly reached by a pipe from the area where our hypothetical main castellum aquae would be located.

After having discussed the whereabouts of the right channel and that found at Sant Just, the left branch would have been aimed at meeting other needs and in a different area of the city. The first indication towards this is the difference in the channel height. Presumably, this channel was not intended to reach the highest spot in the city but a much lower area. Also, being at the left side, it probably discharged in the northern area of the city, thus avoiding crossing paths with the right aqueduct. The underground channel found at Pietat Street (Fig. 4a) could have served as an indication of the left channel route towards Sant Iu collegium and the industrial area of the city, where a copious water supply would have been needed, given the structures discovered and the nature of the activities involved. The hydraulic configuration of the structures at Sant Iu suggests a constant water flow. A water channel $0.24 \mathrm{~m}$ wide and with a $8.2 \%$ slope has been found in this collegium. These structures and the public character of the building may attest to this area's connection to the public water distribution system.

The water evacuation system of Barcino follows a standard layout. As Beltrán de Heredia and Carreras stated (2011), the city's sewage system followed the central axis of the streets until they reached the city walls where, after passing under the walls, they discharged into the city's ditch. This would be undoubtedly aided by the marginal position of industrial installations and thermae, close to the walls, in the lower parts of the city. The proper function of the sewage system was undoubtedly aided by the sloped topography of the city and the constant discharge of water brought by the aqueduct. Not being able to stop the aqueduct's flow, most of the supplied water went straight into the sewage system keeping, in this way, the drains flushed out (Hodge 2000, p. 48). In this sense, most drains documented in the city follow a northeast-southwest orientation, the same to that of the city's cardines under which they run. However, it is curious that only one sewer has been found with the same orientation as the city's decumani, and it was located just outside the southern city gate, probably discharging at the neighbouring sea. It is possible that few public sewers followed the decumani orientation in Barcino. This would be in accordance with the topography (in which the upper areas follow its longitudinal axis) and layout (much shorter at Northeast-Southwest side) of the city. No doubt the cardines orientation would have been preferred to that of the decumani, as an artificial gradient would have had to be cut in order for the sewers to function properly. Also, the waste deposited in sewers at the northern part of the city following its longitudinal axis would have had to traverse the whole city-in which case the midway topographic depression would have been a major problem (Fig. 4) before draining outside the walls at the southern extreme, where no ditches have been found; instead one of the city's public baths and a private bath complex was located there. In this regard, it is no wonder all documented drains follow the cardines' axis.

As documented in Palma de Sant Just Street and in the church of Sant Just i Pastor, water was delivered from the main conduit along the city ridge, following the natural 
gradient in the direction of the cardines. This would be consequent with the location and orientation of the documented sewers: once the waters, coming downward from the city's topographic ridge, had been used which, one might argue, was only a minor delay in their continuous movement, they were dispelled through drains following the same orientation. In this way, Barcino's water network is quite simple in its conception but highly efficient. Cleaning the city ditch, where all the waste of the city were accumulated, was contingent upon rains which, aided by the topography of the city's periphery, would transport the waste to the sea.

The social use of water in Barcino

In Barcino we see how water was divided according to its usage: drinking water, industrial, religious and recreational. Industrial and recreational uses employed open channels with no traces of opus signinum hydraulic mortar in their walls. Potable water, on the contrary was supplied by means of pressurised lead conduits to private citizens. A good example of this double system is illustrated by the Bisbe Caçador domus, which accessed both pressurised and open channel water distribution systems. In addition to open flow and pressurised water distribution many private residences, such as the Sant Honorat domus and probably public buildings such as Sant Iu, made use of rain run-off from roof and courtyards and underground water from wells (Fig. 4). Taking into account that the Roman period in Spain was wetter than it is today (Riera et al. 2009) this might have accounted for a significant supply.

Therefore, although conditioned by the city's topography, water distribution systems in Barcino were mostly related to water use and a clear division between water destined for public and private use cannot be drawn. Although domestic water use was probably supplied by means of pressurised lead pipes, which allowed measuring and taxing private water consumption through an annual vectigalia, private baths would have also been supplied with aqueduct water by free-flow channels. Probably this is related to the availability of water: considering the colony's size, the quantity of water available at Montcada springs, and the use of alternative sources to aqueduct water, Barcino would have not been pressed towards water rationing, which could also further explain lack of cisterns as attested archaeologically. Consequently, the configuration of the water system seems also to point to a continuous water flow. The availability of water in the colony is further illustrated by the Minicii family's evergetism that led to the construction of an enormous bath complex for the citizenry, which tapped public sources with no opposition from the colony's authorities. All excavated private houses in this small-sized city were provided with a bath complex, which not only points to the high status of its citizens but also to the municipality effort to supply the city with a copious amount of good quality water.

\section{Conclusions}

In-depth examination of previous theories and comprehensive synthesis of all the available archaeological, documentary and topographic data regarding the supply, distribution and use of water have allowed a reconstruction of the whole water system of Barcino. The results of this study are innovative, substantially revising previous knowledge. The evidence leads to the new idea that Barcino was supplied by only one aqueduct, the route and construction techniques of which are consistent with standard Roman practices. Water 
supply in the city was conditioned by the different usages of water but also by the city's irregular topography, which forced Roman engineers to divide the aqueduct before it entered the city.

Furthermore, the techniques employed in this research, based on those usually employed in landscape archaeology, permitted georeferencing of multiple data types related to the study of water and their analysis in a three-dimensional setting. The conjunction of diverse types of sources and evidence allowed going beyond the reconstruction of the water system to reach conclusions regarding the social status of the city's inhabitants. In a colony like Barcino, which was created ex novo to play a key political, administrative and religious role (Cortés 2011), the presence of a monumental aqueduct and, as a consequence, public and private baths, fountains, public ponds and drainage system need to be interpreted not simply as functional but as covering an essential symbolic role (Koloski-Ostrow 2001, p. 4) through which the city's romanitas was clearly asserted.

Acknowledgments The authors would like to express their gratitude to the numerous professional contract archaeologists, too many to quote here, the copious work of which resulted in a wealth of essential information in order to understand Barcino's water system. Our thanks also to the two anonymous reviewers who helped improve this paper with their comments.

Open Access This article is distributed under the terms of the Creative Commons Attribution License which permits any use, distribution, and reproduction in any medium, provided the original author(s) and the source are credited.

\section{References}

Aguelo J, Juárez T, Subiranas C (2011) Intervenció arqueològica a les portes de la ciutat de Barcelona: l'exemple de l'avinguda de Vilanova, 3-11/carrer Roger de Flor, 39-43. Tribuna d'Arqueologia 2009-2010:331-357

Arenillas M, Barahona M, Gutiérrez F, Cauce C (2009) El abastecimiento de agua a Toledo en época romana. Confederación hidrográfica del Tajo, Toledo

Balari Jovany J (1964) Orígenes históricos de Cataluña. Instituto Internacional de Cultura Románica, San Cugat del Vallés

Beltrán de Heredia J, Carreras C (2011) Barcino. In: Remolà JA, Acero JA (eds) La gestión de los residuos urbanos en Hispania. Xavier Dupré Raventós (1956-2006). In memoriam. Instituto de Arqueología de Mérida, Mérida, pp 233-254

Blasco M, Granados JO, de Laorden V, Miró C, Prada JL, Piquer E, Puig F, Rovira C (1992) L'avinguda de la Catedral; de l'ager de la colònia de Barcino a la Vilanova dels Arcs. Ajuntament de Barcelona, Barcelona

Borau C (2003) Els promotors de capelles i retaules a la Barcelona del segle XIV. Fundació Noguera-Lleida, Barcelona

Bosarte I (1786) Disertación sobre los monumentos antiguos pertenecientes a las nobles artes de la pintura, escultura y arquitectura que se hallan en la ciudad de Barcelona. Antonio de Sancha, Madrid

Caballé F, Cazeneuve X, Gonzàlez R, Nolasco N (2002) Estudi històrico-arquitectònic de la finca núm. 25 del carrer Ripoll de Barcelona. Unpublished report, Centre de Documentació del MUHBA

Call i Franqueza D (1878) Colección de los artículos que con el epígrafe "Mejoras de Barcelona" publicó en el Diario de Barcelona. Suc. de Ramírez y Cia, Barcelona

Carbonell PM (1547) Chroniques de Espanya. Barcelona

Carreras Candi F (1905) Les aygues y banys de Barcelona. Miscel-lània Històrica Catalana, serie I. Barcelona

Carreras Candi F (1916) Geografia general de Catalunya. La Ciutat de Barcelona, Barcelona

Céan Bermúdez JA (1832) Sumario de las Antigüedades romanas que hay en España, en especial las pertenecientes a las Bellas Artes. Madrid 
Cortés A (2009) L'arquitectura domèstica de les ciutats romanes de Catalunya. Época tardorepublicana i altimperial. Unpublished PhD, Universitat Autónoma de Barcelona

Cortés A (2011) L'arqueitectura domèstica de la ciutat romana de Barcino. Quaderns d'Arqueologia i Història de la Ciutat de Barcelona, època II 7:16-66

Crow J, Bardill J, Bayliss R (2008) The water supply of byzantine constantinople. J Roman Stud Monograph 11

Duran i Sanpere A (1962) La lucha por el agua, in El agua en la vida cotidiana. Centro de Estudios, Investigación y Aplicaciones del Agua, Barcelona, pp 6-27

Duran i Sanpere A (1972) Barcelona i la seva història. La formació d'una gran ciutat. Barcelona, Curial

Fabre G, Fiches JL, Leveau P (2005) Recherches recents sur les aqueducs romains de Gaule méditerranéenne. Galia 62:1-170

Fernández Casado C (1972) Acueductos romanos en España. CSIC, Madrid

Fiz I, Orengo HA (2008) Simulating communication routes in Mediterranean alluvial plains. In: Posluschny A, Lambers K, Herzog I (eds) Layers of perception. (Kolloquien zur Vor- und Frühgeschichte, 10). Habelt, Bonn, pp 316-321

Florensa F, Gamarra A (2006) L'excavació del jaciment arqueològic del carrer Sant Honorat 3 de Barcelona. Tribuna d'Arqueologia 2003-2004:189-209

Forbes RJ (1955) Studies in ancient technology, vol 1. Leiden, E.J. Brill

Giner D (2006) Memòria de la intervenció arqueològica preventiva al C/. Coronel Monasterio 6-16 (Barcelona, el Barcelonès). Març_agost de 2004. Unpublished report, Centre de Documentació del MUHBA

Griño D (2005) Memòria de la intervenció al carrer de les Magdalenes, 25. Unpublished report, Centre de Documentació del MUHBA

Guendon JL, Leveau Ph (2005) Dépôts carbonatés et fonctionnement des aqueducs romains : le bassin amont du vallon des Arcs sur l'aqueduc d'Arles (Bouches-du-Rhône). Gallia 62:87-96

Hernández-Gasch J (2006) The castellum of Barcino: from its early Roman Empire origins as a monumental public place to the late antiquity fortress. Quaderns d'Arqueologia i Història de la Ciutat de Barcelona, època II 2:74-91

Hodge AT (1989) Aqueducts, in Roman public buildings, ed. University of Exeter, I.M. Barton. Exeter, pp 127-149

Hodge AT (2000) I.5. Aqueducts. In: Wikander Leiden O (ed) Handbook of ancient water technology. Köln, Brill, Boston, pp 39-65

Hodge AT (2002) Roman Aqueducts \& Water Supply, 2nd edn. Bristol Classical Press, London

Iorba DH (1589) Descripcion de las excellencias de la muy insigne ciudad de Barcelona. Barcelona

Kelly A (2006) The Impact of Constructing Aqueducts on the Settlement Patterns of Roman Crete, in Cura Aquarum in Ephesus, Volume II. Peeters Publishers, Leuven, pp 303-310

Koloski-Ostrow O (2001) Water as a symbol of wealth? An overwiew of the roman evidence. In: KoloskiOstrow O (ed) Water use and hydraulics in the Roman city, in water use and hydraulics in the Roman city. (Archaeological Institute of America, Colloquia and Conference Papers, 3). Kendall/Hunt Publishing Company, Dubuque, pp 1-15

Koloski-Ostrow O, Crouch DP, de Haan N, Bruun C, Leigh S, Wilson A (2001) An epilogue: where to go from here? Future courses of water studies. In: Koloski-Ostrow O (ed) Water use and hydraulics in the Roman city. Archaeological Institute of America, Colloquia and Conference Papers, vol 3. Kendall/ Hunt Publishing Company, Dubuque, pp 97-104

Laborde A (1974) Viatge Pintoresc i Històric. El Principat. Publicacions de l'Abadia de Montserrat, Barcelona

Lagóstena LG, de B. Zuleta F (2009) Gades y su acueducto: una revisión. In: Lagóstena LG, de B. Zuleta F (eds) La captación, los usos y la administración del agua en Baetica: Estudios sobre el abastecimiento hídrico en comunidades cívicas del Conventus Gaditanus, coords. Servicio de Publicaciones de la Universidad de Cádiz, Cádiz, pp 115-170

Leveau $\mathrm{Ph}$ (2004) L'archéologie des aqueducs romains ou les aqueducs romains entre Project et usage, in Elementos de Ingeniería Romana. Colegio de Ingenieros Técnicos de Obras Públicas, Tarragona, pp 105-134

Lewis MJT (2001) Surveying Instruments of Greece and Rome. Cambridge University Press, Cambridge López J (2008) L'Aqüeducte del Gaià. In: Vergés JM, López J (eds) Valls i la seva història. Volum II. Prehistòria i història antiga, coords. Institut d'Estudis Vallencs, Valls, pp 365-368

Malissard A (2001) Los romanos y el agua. Herder, Barcelona

Marín S (2007) Memòria del sondeig arqueològic realitzat a la finca núm. 5 del carrer del Paradís de Barcelona. Unpublished report, Centre de Documentació del MUHBA 
Martín JM (2007) Aigua i societat a Barcelona entre les dues exposicions (1888-1929). Unpublished PhD, Departament d'Història Moderna i Contemporània. Universitat Autònoma de Barcelona

Mayer M, Rodà I (1977) El abastecimiento de aguas en la Barcelona romana. Reconstrucción de su trazado. In: Segovia y la Arqueología romana, actas del Symposium de Arqueología romana. Institut d'Arqueologia i Prehistòria, Barcelona, pp 265-277

Mestres JO (1893) Memoria en la que se combaten las suposiciones consignadas en el folleto escrito por el Dr. D. Pablo Valls y Bonet. Barcelona, Imprenta de Jaime Jepús Roviralta

Miró N (1998) Memòria de la intervenció arqueològica al carrer Argenteria. Unpublished report, Centre de Documentació del MUHBA

Miró C (2011a) Els balnearis terapèutics romans, origen de la ciutat embadalida. In: Costa A, Palahí L, Vivó D (eds) Aquae Sacrae. Agua y sacralidad en la Antigüedad. Universitat de Girona, Girona, pp 115-140

Miró C (2011b) Els balnea de les domus de Barcino. Quaderns d'arqueologia i història de la ciutat de Barcelona, època II 7:68-83

Miró C, Orengo HA (2010) El cicle de l'aigua a Barcino. Una reflexió entorn a les noves dades arqueològiques. Quaderns d'arqueologia i història de la ciutat de Barcelona, època II 6:108-133

Orengo HA, Fiz I (2008) The application of 3D reconstruction techniques in the analysis of ancient Tarraco's urban topography. In: Posluschny A, Lambers K, Herzog I (eds) Layers of perception. (Kolloquien zur Vor- und Frühgeschichte, 10). Habelt, Bonn

Orengo HA, Cortés A (2014). The Augustan temple and forum of the colony of Barcino: a 90 degrees turn. Oxford J Archaeol 33(1) (in press)

Orengo HA, Miró C (2011) Following Roman waterways from a computer's screen. GIS-based approaches to the analysis of Barcino's aqueducts. In: Verhagen JWH, Posluschny AG, Danielisova A (eds) Go your own least cost path. Spatial technology and archaeological interpretation (BAR S2284). Archaeopress, Oxford, pp 47-53

Ortí P (2012) El Rec Comtal de la Barcelona medieval, Romana. In: Guàrdia M (ed) La revolució de l'aigua a Barcelona. De la ciutat preindustrial a la metròpoli moderna, 1867-1967. Ajuntament de Barcelona, Barcelona, pp 21-25

Ortloff CR, Crouch DP (2001) The urban water supply and distribution system of the Ionian city of Ephesos in the Roman Imperial period. J Archaeol Sci 28:843-860

Owens EJ (1991) The Kremna aqueduct and water supply in Roman cities. Greece \& Rome, 2nd series 38(1), pp 41-58

Padrós P (1999) El suministro de agua y la red de colectores en la ciudad romana de Baetulo (Badalona). In: Rodríguez A (ed) Los orígenes de la ciudad en el noroeste hispánico: actas del Congreso Internacional, Vol. 1. Diputación Provincial de Lugo, Lugo, pp 599-622

Palet JM (1997) Estudi territorial del Pla de Barcelona. Estructuració i evolució del territori entre l'època iberoromana i l'altmedieval. Segles II-I aC-X-XI dC. (Estudis i Memòries d'Arqueologia de Barcelona 1). Ajuntament de Barcelona, Barcelona

Palet JM, Orengo HA, Riera-Mora S (2011) Centuriación del territorio y modelación del paisaje en los llanos litorales de Barcino (Barcelona) y Tarraco (Tarragona): una investigación interdisciplinar a través de la integración de datos arqueomorfológicos y paleoambientales. Agri Centuriati. International Journal of Landscape. Archaeology 7(2010):113-129

Ponz A (1788) Viage de España en que se da noticia de las cosas mas apreciables, y dignas de saberse, que hay en ella. vol XIV. Imprenta de la Viuda de Ibarra, Hijos, y Compañía, Madrid

Puente S (2005) Memòria científica del control arqueològic al carrer Paradís núm 12. Unpublished report, Centre de Documentació del MUHBA, Barcelona

Puig F, Rodà I (2007) Las murallas de Barcino. Nuevas aportaciones al conocimiento de la evolución de sus sistemas de fortificación. In: Murallas de ciudades romanas en el occidente del Imperio: Lucus Augusti como paradigma. Diputación provincial, Lugo, pp 595-631

Pujades J (1829) Crónica Universal del Principado de Cataluña, escrita a principios del siglo XVII. vol. 1. Reprint form the original work of 1609. Imprenta de José Torner, Barcelona

Riera S, Curras A, Palet JM, Ejarque A, Orengo HA, Julià R, Miras Y (2009) Variabilité climatique, occupation du sol et gestion de l'eau en Espagne de l'Âge du Fer à l'époque médiévale: intégration des données paléo-environnementales et archéologiques. In: Hermon E (ed) Changements climatiques dans une perspective historique et systémique des interactions société-environnement naturel dans l'empire romain. Université Laval, Québec, pp 251-280

Rodà I (1974) El origen de la vida municipal y la prosopografía romana de Barcino. Universidad Autónoma de Barcelona, Barcelona

Roldán L, Baena J, Blasco C, Bermúdez J, García E (1999) SIG y arqueología romana. Restitución del trazado del acueducto de Cádiz. In: Baena J, Blasco C, Quesada F (eds) Los S.I.G. y el análisis espacial en arqueología. Ediciones de la Universidad Autónoma de Madrid, Madrid, pp 255-72 
Schwartz F, Carreras Candi F (1892) Manual de Novells Ardits, vulgarment apellat Dietari del Antich Consell Barceloní. Volúm primer, comprenent los volúms originals del I al IX. Anys 1390-1446. Barcelona: Henrich i Companyia

Serra i Rafols J (1967) Balanç i estat actual de l'estudi de la muralla romana de Barcelona. Cuadernos de Arqueologia e Historia de la ciudad X, pp 129-148

Soberón M (2005) Memòria de la intervenció al carrer de les Magdalenes, 25. Barcelona. 039-05. MHCB. Inèdita. Centre de Documentació del MUHBA

Socies F (1650) Llibre de las fonts de la present ciutat de Barcelona. Arxiu Històric de la Ciutat de Barcelona

Sol J (1977) Notas sobre unas catas efectuadas en el solar de la casa n 3 de la calle Arcs, de Barcelona, intentando situar el acueducto romano, in Segovia y la Arqueología romana, actas del Symposium de Arqueología romana. Institut d'Arqueologia i Prehistòria, Barcelona, pp 377-382

Travesset M (2005) Origen del Rec Comtal i del subministrament d'aigua a la Barcelona de l'època romana. Finestrelles 13:41-72

Unzu M, Prieto P, Peréx MJ, Hernando A (2006) Roman Baths in Pamplona (Navarra, Spain), in Cura Aquarum in Ephesus, vol 2, ed. G. Wiplinger. Peeters, Leuven, pp 431-435

Van Leusen M (2002) Pattern to process: methodological investigations into the formation and interpretation of spatial patterns in archaeological landscapes. Unpublished $\mathrm{PhD}$, Univeristy of Leiden

Ventura A (1996) El abastecimiento de agua a la Córdoba romana II. Acueductos, ciclo de distribución y urbanismo. Universidad de Córdoba, Córdoba

Vila P, Casassas L (1974) Barcelona i la seva rodalia al llarg del temps. Aedos, Barcelona

Villanueva J (1851) Viage literario a las iglesias de España, vol XVIII. Real Academia de la Historia, Madrid

Voltes Bou P (1967) Historia del abastecimiento de agua a Barcelona. Sociedad General de Aguas de Barcelona, Barcelona

Wilson A (2001) Urban water storage, distribution, and usage in Roman North Africa. In: Koloski-Ostrow O (eds) Water use and hydraulics in the Roman City (Archaeological Institute of America, Colloquia and Conference Papers, 3). Kendall/Hunt Publishing Company, Dubuque, pp 83-96

\section{Author Biographies}

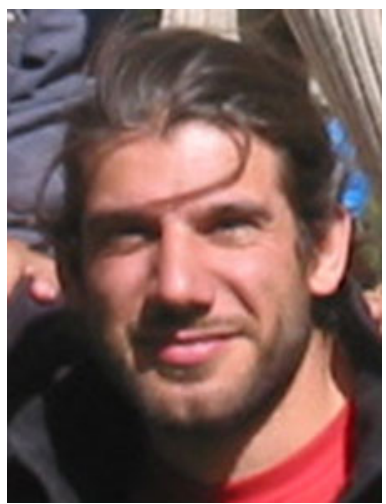

Hector A. Orengo is a Nottingham Advance Research Fellow in the Department of Archaeology of the University of Nottingham. He has previously worked in the Catalan Institute of Classical Archaeology and in the GEOLAB (University of Limoges - CNRS). He is specialised in Landscape and Classical Archaeology and has directed fieldwork in Spain, Andorra, France and Greece. 


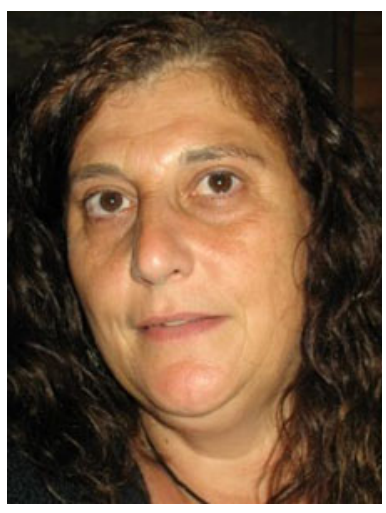

Carme Miró i Alaix is Head of the Plan of Urban Archaeology of Barcelona, Director of the 'Plan Barcino' and Head of the Documentation Centre of the Service of Archaeology of Barcelona. She has 23 years of archaeological experience and during this period she has specialised in Urban Archaeology, Heritage Management and ancient baths. 